\title{
A CHEGADA DO HOMEM À LUA E A PRODUÇÃO DO PRÉ-LIVRO CÉU AZUL (RIO GRANDE DO SUL, EDITORA TABAJARA, 1970) ${ }^{1}$
}

\author{
MAN'S ARRIVAL TO THE MOON AND THE PRODUCTION OF THE CÉU AZUL PRE-BOOK \\ (RIO GRANDE DO SUL, TABAJARA PUBLISHING COMPANY, 1970)
}

\author{
Chris de Azevedo Ramil \\ Universidade Federal de Pelotas \\ chrisramil@gmail.com \\ Eliane Peres \\ Universidade Federal de Pelotas \\ eteperes@gmail.com
}

\section{RESUMO}

Este artigo resultou de um estudo do pré-livro Céu Azul, de coautoria das professoras gaúchas Rosa M. Ruschel e Flávia E. Braun e que foi publicado, em 1970, pelas Edições Tabajara, do Rio Grande do Sul. A análise foi baseada na perspectiva da iconografia e da iconologia, uma vez que o foco são as ilustrações de Céu Azul. Para tanto, os autores de referência são Panofsky (1986); Burke (2004; 2017); Ramil (2018). A narrativa do pré-livro - textos e ilustrações - faz referência a um dos acontecimentos mais marcantes da história da humanidade, ocorrido em 20 de julho de 1969: a chegada do homem à Lua. Como resultados principais, identificou-se o uso de ilustrações originais, de releituras de imagens da época, associadas ao método global de contos. Destaca-se, também, que, como um artefato de seu tempo, Céu Azul revela as relações entre o mercado editorial didático, a sala de aula, os acontecimentos sociais, culturais, políticos e tecnológicos de um determinado momento e as intencionalidades pedagógicas.

Palavras-chave: Pré-livro, método global, ilustrações, Céu Azul, homem na Lua.

\section{ABSTRACT}

This article resulted from a study of the primer entitled Céu Azul, co-authored by school teachers from Rio Grande do Sul, Rosa M. Ruschel and Flávia E. Braun, which was published in 1970 by Edições Tabajara, from the same State. The analysis was based on the perspective of iconography and iconology, since the main focus is the illustrations of Céu Azul. For that, the reference authors are Panofsky (1986); Burke (2004; 2017); Ramil (2018). The primer narrative - texts and illustrations - makes reference to one of the most remarkable events in human history, which took place on July 20, 1969: the arrival of man on the Moon. As main results, it was identified the use of original illustrations, reinterpretations of images of the time, associated with the whole word method. It stands out, too, that as an artifact of its time, Céu Azul reveals the relationships between the didactic publishing market, the classroom, the social, cultural, political and technological events of a given moment and the pedagogical intentions.

Keywords: Primer, whole word method, illustrations, Céu Azul, man on the Moon.

\footnotetext{
1 Uma primeira versão deste trabalho foi apresentada no $25^{\circ}$ Encontro da Associação Sul-Rio-Grandense de Pesquisadores em História da Educação (ASPHE) e publicada nos Anais do referido evento, no ano de 2019, pela Universidade Federal do Pampa - Unipampa, de Bagé/ RS. O artigo aqui apresentado é uma versão revista, atualizada e ampliada desse estudo.
} 


\section{Introdução}

O Rio Grande do Sul foi um importante polo de produção de livros didáticos desde o século XIX, realidade que se intensificou ainda mais no século XX, especialmente entre os anos de 1940 e o final da década de 1970. Isso se deve, principalmente, à política instituída por um importante órgão do estado gaúcho, o Centro de Pesquisa e Orientações Educacionais (CPOE), criado em 1942 e instalado em 1943, ligado à Secretaria de Educação e Cultura do Rio Grande do Sul. O CPOE foi responsável pelas orientações e regulamentações do ensino gaúcho na segunda metade do século XX. De sua criação, no início dos anos de 1940, até o encerramento de suas atividades, no início da década de 1970², o CPOE desenvolveu importante papel no ensino gaúcho, inclusive no que diz respeito à produção e circulação de livros didáticos, uma vez que, especialmente a partir dos anos de 1950, o órgão foi responsável pelo fomento da produção didática no Rio Grande do Sul (RS). Além disso, estava a seu cargo a elaboração de programas e planos escolares que determinavam os modelos pedagógicos em vigor no estado naquela época e os livros didáticos precisavam, assim, estar de acordo com esses programas e planos (PERES, 2000; QUADROS, 2006).

As mulheres profissionais vinculadas a esse órgão, chamadas técnicas educacionais, se especializaram na produção didática em todas as áreas de conhecimento e para todas as séries do ensino primário (PERES, 2000; 2003). O fenômeno da produção de cartilhas ou pré-livros, como também eram chamados os livros para o ensino inicial da leitura e da escrita, teve especial atenção no campo educacional e editorial gaúcho (PERES; RAMIL, 2015). Isso se deve, muito especialmente, em razão da produção, divulgação e utilização do método global de ensino da leitura e da escrita, especialmente entre os anos de 1950 e 1970, amplamente defendido pelo CPOE e pelas especialistas educacionais a ele ligadas.

Nesse contexto, foi produzido o pré-livro Céu Azul, publicado em 1970 pela Editora Tabajara, do Rio Grande do Sul, uma coautoria das professoras gaúchas Rosa M. Ruschel e Flávia E. Braun. O exemplar analisado neste artigo é parte de um dos acervos do centro de memória e pesquisa Hisales ${ }^{3}$, o dos livros didáticos produzidos por autoras e/ou editoras gaúchas, cujo montante soma atualmente 392 exemplares (dados de outubro de 2020). Desses, 103 foram publicados pelas Edições Tabajara, uma empresa editorial gaúcha, de Porto Alegre/RS, reconhecida e com expressiva circulação de publicações, principalmente as didáticas, que extrapolaram os limites da região sul do país e foram utilizadas inclusive em outros estados do Brasil com altas tiragens e muitas reedições (RAMIL, 2018; VIEIRA et al., 2013). Entre esses exemplares da Editora Tabajara que fazem parte do referido acervo, está o pré-livro Céu Azul, foco do presente artigo.

Neste artigo, são analisadas principalmente as ilustrações presentes nas páginas da referida publicação, além do método utilizado para o ensino da leitura e da escrita, especialmente devido ao fato de ambos fazerem referência a um dos acontecimentos mais conhecidos e repercutidos mundialmente até os dias de hoje, que ocorreu no dia 20 de julho de 1969, quando o homem chegou à Lua pela primeira vez, fato este que foi considerado "[...] um pequeno passo para o homem, mas um grande salto para a humanidade", conforme foi pronunciado pelo astronauta Neil A. Armostrong, naquele ato (FOTOS PÚBLICAS, 2021; NASA, 2019).

2 A partir da reorganização da Secretaria de Educação e Cultura (SEC) do Rio Grande do Sul, determinada pelo Decreto n 21.120 , de 17 de maio de 1971, com a implantação de um novo modelo de gestão educacional, o CPOE/RS teve suas atividades encerradas (QUADROS, 2006).

3 O Hisales - História da Alfabetização, Leitura, Escrita e dos Livros Escolares - é um centro de memória e de pesquisa vinculado à Faculdade de Educação (FaE) da Universidade Federal de Pelotas (UFPel), situado em Pelotas/RS. O Hisales, atualmente, possui seis principais acervos, entre outros complementares: a) cadernos de alunos (ciclo de alfabetização e outros); b) cadernos de planejamento de professoras; c) livros para o ensino inicial da leitura e da escrita nacionais e estrangeiros; d) livros didáticos produzidos no Rio Grande do Sul entre 1940 e 1980; e) materiais didático-pedagógicos: f) escritas pessoais e familiares. Mais informações a respeito do Hisales, dos acervos, das ações, dos projetos de pesquisa, de ensino e de extensão, podem ser vistas via internet, no site (http://www.ufpel.edu.br/fae/hisales/) e nos perfis nas redes sociais Facebook e Instagram (@hisales.ufpel). 
Para realização do estudo, os procedimentos metodológicos adotados foram os seguintes: a) digitalização do referido pré-livro e tratamento das imagens - para uso no estudo e integração no banco de dados virtual (evitando-se também o desgaste físico do único e raro exemplar); b) leitura do conjunto das narrativas e estudo das ilustrações uma a uma; c) coleta de dados - levantamento das informações a serem analisadas a partir da observação do suporte como um todo (capa, contracapa/quarta capa ${ }^{4}$, páginas pré-textuais, páginas textuais e páginas pós-textuais5); d) organização dos dados - registro de dados editoriais, gráficos e descrição e cruzamento das informações sobre o método de ensino da leitura e da escrita (as historietas) associado às ilustrações; e) levantamento de imagens históricas (sites, revistas, livros) relativas ao episódio da chegada do homem à Lua, em 1969, para fins de comparação com as ilustrações do pré-livro; f) análise dos dados reunidos e apresentação dos resultados.

Considerando isso, a presente análise pautou-se na perspectiva da iconografia e da iconologia. A primeira entendida como o estudo da imagem através da composição e da disposição dos elementos que as constituem; a segunda, como sendo o estudo da imagem através da interpretação do significado, pelo contexto cultural e histórico, pelo valor simbólico da estética imagética etc. A iconografia e a iconologia se complementam na construção de um conhecimento efetivo e reflexivo sobre o conteúdo das imagens. Esses conceitos são defendidos por Panofsky (1986), um historiador da arte e crítico alemão, considerado um dos principais representantes dessa metodologia de leitura de imagens. A partir dessa referência, considerou-se oportuno o investimento nessa perspectiva para o estudo das imagens nos livros didáticos, conforme também pode ser conferido em pesquisa anteriormente realizada (RAMIL, 2018).

Para apresentação dos resultados do estudo, este artigo foi dividido em duas seções: na primeira, descrevem-se a materialidade do artefato e os aspectos do método e da estrutura do pré-livro Céu Azul; na segunda, especificamente as ilustrações são analisadas, comparando com imagens históricas da chegada do homem à Lua. Assim sendo, o objetivo do artigo é contribuir com o campo da história da alfabetização a partir do estudo específico de um artefato produzido para alfabetizar as crianças no âmbito da política gaúcha de educação, demonstrando o potencial de análise das ilustrações do livro didático, aqui designadamente no campo da iconologia e da iconografia.

\section{Aspectos da materialidade, do método e da estrutura do pré-livro Céu Azul}

Destaca-se, inicialmente, que abordar o livro didático é ocupar-se com um dos mais significativos artefatos da cultura escolar. Escolano Benito (2017, p. 199) afirma que os livros escolares são "um dos expoentes mais claros e mais bem recordados da cultura da escola". Eles expressam não apenas concepções pedagógicas e de ensino e aprendizagem, mas também os acontecimentos de um tempo e espaço e a cosmovisão de uma sociedade em um dado período. Trata-se, pois, de um artefato que manifesta valores, sentidos, interesses e discursos autorizados de um determinado momento histórico.

4 Na sequência do texto, será utilizada apenas a nomenclatura "contracapa" ao referir-se a essa parte do livro. Vale destacar que para pesquisadores da área gráfica (ARAÚJO, 1986; entre outros), a parte de trás do livro, que o encerra, compondo o invólucro da obra junto com a capa, pode ser chamada de contracapa, quarta capa ou $4^{a}$ de capa. Já entre os pesquisadores da área da educação, é mais comum a utilização da definição de quarta capa para essa última parte, externa, e que fecha o livro por trás, pois, para eles, a nomenclatura de contracapa é identificada como sendo o lado interno da capa (o que corresponde, também, entre as 4 capas, à segunda capa).

5 Um livro pode ser dividido em quatro partes: pré-textual, textual, pós-textual e extratextual. A parte pré-textual reúne os elementos como: folha de rosto, dedicatória, epígrafe, sumário, prefácio, agradecimentos, introdução, entre outros. Já a parte textual é formada pelo texto do livro e suas divisões, as chamadas seções ou capítulos. A parte pós-textual é composta por posfácio, apêndice, glossário, bibliografia, índice, incluindo também outros elementos, como o cólofon, por exemplo. A parte extratextual refere-se à capa, a qual se divide em: primeira capa, segunda capa, terceira capa, quarta capa ou contracapa, primeira orelha, segunda orelha, sobrecapa e lombada (ARAÚJO, 1986; RAMIL, 2013). 
Além disso, para Batista (1999), o livro didático é efêmero, se desatualiza com muita velocidade e sua utilização está ligada aos intervalos de tempo escolar. No caso de Céu Azul, sua proposta e conteúdo - enfoque na chegada do homem à Lua - revelam essa efemeridade e um intervalo de tempo bastante circunscrito. Contudo, como mercadoria que necessita ser vendável (MUNAKATA, 1997; BITTENCOURT, 2008), é preciso destacar quão apropriada e oportuna foi a ideia de usar um dos acontecimentos de maior repercussão do século para produzir um livro para o ensino inicial da leitura e da escrita. Como sujeitos de seu tempo, autoras(es), ilustradoras(es), editoras(es), gráficas, inseridos em um "circuito das comunicações" (DARNTON, 2008; 2010) 6 e atendendo a um público e um mercado bastante específicos - alunos e professores e, via de regra, o "Estado comprador" -, ao produzirem, ilustrarem, editarem, publicarem livros de destinação escolar estão atentos, entre outros aspectos, às prescrições oficiais, às inovações pedagógicas, ao público destinado, às demandas do mercado, ao contexto histórico, político e social. Céu Azul é um exemplo bastante pertinente dessa assertiva, revelando que uma obra didática resulta de seu tempo, tanto do ponto de vista pedagógico quanto do social, político e ideológico.

Como já referido, o pré-livro Céu Azul tem a coautoria de Rosa M. Ruschel e Flávia E. Braun, ambas professoras gaúchas, e foi publicado pelas Edições Tabajara. As ilustrações e a capa são de Therezinha Tabajara Baims. O volume analisado no presente artigo corresponde à primeira edição, do ano de 1970, da qual foram publicados 20.000 exemplares. Contém 70 páginas, mede 13,8 cm × 20,8 cm, com 0,5 cm de lombada e foi impresso na AGGS Indústrias Gráficas S.A.

Consta nas páginas pré-textuais que esse pré-livro exigiria, para a aplicação do método nele contido, o Manual do Professor, contudo, não se dispõe do referido Manual. Todavia, sabe-se que os manuais traziam todas as orientações de "aplicação do método". Na listagem de publicações da editora, presente na contracapa, consta a indicação do referido pré-livro, mas com a denominação "Cartilha", e também do Manual para o Professor, ambos sob o título de Céu Azul. Entretanto, na capa do exemplar, a referência é pré-livro. Tratava-se de uma designação, à época, que procurava associar o artefato ao método que apregoava: o de contos, que se destacará adiante.

A Tabajara, naquela época, era sediada em Porto Alegre/RS (Rua das Andradas, n. 1774), contava com uma filial na cidade de São Paulo/SP (Rua Santa Efigênia, n. 72) e utilizava os serviços de produção gráfica de empresas terceirizadas, como é o caso da AGGS supracitada, sediada no Rio de Janeiro/RJ. Fundada em 1943, foi uma das casas editoriais mais importantes do Rio Grande do Sul, com publicação expressiva de livros didáticos, tendo encerrado as suas atividades em meados dos anos de 1980 em razão de dificuldades para manutenção dos negócios, também decorrentes da crise financeira enfrentada por várias editoras gaúchas que perdiam seu espaço para as grandes editoras do eixo Rio de Janeiro-São Paulo, no período (RAMIL, 2018).

Sobre as autoras, ambas foram professoras nas cidades gaúchas de Estrela/RS e Porto Alegre/RS. Antes da Céu Azul, já haviam publicado a Coleção Guri, bastante conhecida e utilizada no estado gaúcho. As produções dos referidos livros e a coautoria estabelecida também se devem às relações prévias entre as autoras, tanto pelo relacionamento pessoal de amizade como pelas trajetórias profissionais semelhantes e pela atuação profissional nas mesmas instituições (RAMIL, 2018). Vale referenciar também que ambas integram o rol das 58 professoras autoras gaúchas de livros didáticos produzidos entre os anos de 1940 e 1980, que foram identificadas em estudo anterior (PERES; RAMIL, 2018).

6 Segundo Darnton (2010, p. 112), "os livros impressos passam aproximadamente pelo mesmo ciclo de vida. Este pode ser descrito como um circuito de comunicação que vai do autor ao editor (se não é o livreiro que assume esse papel), ao impressor, ao distribuidor, ao vendedor e chega ao leitor. O leitor encerra esse circuito porque ele influencia o autor tanto antes quanto depois do ato de composição. Os próprios autores são leitores. [...] Assim o circuito percorre um ciclo completo. A história do livro se interessa por cada fase desse processo e pelo processo como um todo, em todas as suas variações no tempo e no espaço, e em todas suas relações com outros sistemas, econômico, social, político e cultural, no meio circundante". 
Em relação à ilustradora, Therezinha Tabajara Baims, ela está entre os 14 nomes de ilustradoras e ilustradores identificados nos livros didáticos da Tabajara salvaguardados no acervo do Hisales. Como desenhista técnica, ela atuou junto à Secretaria do Estado em Projetos Escolares (SEPE), do Governo do Estado/RS, entre os anos de 1958 e 1962 . Como o próprio sobrenome indica, ela faz parte da família que era proprietária da editora Tabajara, filha de Aristides Tabajara e sobrinha dos editores Joel Tabajara e Olímpio Tabajara. Seu nome, com a mesma função, ilustradora, aparece em outras publicações didáticas da mesma editora, tais como: Ciências Naturais e Garotos Tevê.

O pré-livro Céu Azul é baseado no método de contos/historietas, que previa seu desenvolvimento em cinco diferentes fases - fase do conto, fase da sentenciação, fase da porção de sentido, fase da palavra e fase da sílaba (MACIEL, 2001; PORTO, 2005). A base teórico-metodológica era o chamado método analítico ou global, cuja máxima era "[...] o sentido fixa a forma" (PENNEL; CUSACK, 1935), ou seja, o entendimento era de que a aprendizagem da leitura seria mais eficaz se partisse de elementos da língua cujo sentido fosse completo: palavra, frase ou conto/historieta (PERES, 2014).

Para o caso do Brasil, a professora Lúcia Casasanta, de Minas Gerais (MG), é considerada a principal idealizadora e divulgadora dessa proposta metodológica de ensino da leitura e da escrita. Algumas publicações produzidas sob influência direta de Casasanta tornaram-se importantes no contexto do ensino inicial da leitura e da escrita, como, por exemplo, O livro de Lili, de autoria de Anita Fonseca, aluna de Lucia Casasanta na Escola de Aperfeiçoamento de Belo Horizonte/MG ${ }^{8}$ (MACIEL, 2001).

Já no Rio Grande do Sul, o CPOE foi o responsável pela produção e divulgação do método global de contos, que ganhou contornos específicos nesse contexto, especialmente entre os anos de 1950 e 1970, período de publicação de Céu Azul. Foi um momento de fértil produção de cartilhas/ pré-livros no estado gaúcho, todos eles baseados no método global de contos, tais como: a) Sarita $e$ seus amiguinhos (Cecy Cordeiro Thofehrn e Jandira Cardias Szechier - Editora do Brasil), b) Estrada Iluminada - Bichano e Zumbi ( $1^{\circ}$ ano) (Cecy Cordeiro Thofehrn e Nelly Cunha - Editora do Brasil); c) Nossa Terra Nossa Gente (Cecy Cordeiro Thofehrn e Nelly Cunha - Editora do Brasil); d) Marcelo, Vera e Faísca (várias autoras ${ }^{9}$ - Editora Tabajara); e) Dedé, José e Tião (Maria de Lourdes Gastal - Editora F.T.D.); f) Juca e Zazá (Eloah Ribeiro Kunz - Editora do Brasil); g) Cartilha do Guri (Élbio N. Gonzales, Rosa Ruschel e Flavia E. Braun - Editora Tabajara); h) Céu Azul (Rosa M. Ruschel e Flavia E. Braun Editora Tabajara), entre outros. ${ }^{10}$

\footnotetext{
7 Depois de trabalhar como ilustradora nas Edições Tabajara e no governo do Estado do Rio Grande do Sul, Therezinha Tabajara Baims teve uma longa trajetória profissional em outros espaços: atuou como artista plástica e como professora a partir de 1977, no Colégio Santa Isabel, em Petrópolis/RJ, nas áreas de História da Arte e Práticas de Conhecimentos Gerais em Desenho e Plástica, por mais de 30 anos. Trabalhou também como professora de desenho e pintura e com restauração de obras de arte. Graduou-se como Bacharel em Artes pela Escola de Belas Artes, do Rio de Janeiro. Atualmente, encontra-se aposentada pelo estado/RJ. Recebeu vários prêmios: menções honrosas em Salões de Arte no Rio Grande do Sul, Rio de Janeiro e Petrópolis/RJ, além de Destaque em Artes e Articuladora do Ensino junto à Secretaria da Educação/RJ.

8 O pré-livro foi publicado pela primeira vez na década de 1930, pela Editora Francisco Alves e, posteriormente, pela Editora do Brasil. Foi um dos maiores sucessos editoriais no país, no que se refere aos pré-livros do método global de contos. Nos mesmos moldes, no Rio Grande do Sul, foi produzida Sarita e seus amiguinhos, nos anos de 1950.

9 Publicação com a coautoria de nove professoras gaúchas: Norma Menezes de Oliveira, Alsina Alves de Lima, Eny Emília Dias da Silveira, Liliana Tavares Rosa, Maria Flora de Menezes Ribeiro, Maria Heoniza Nascimento da Silva, Norma Nunes de Menezes, Marilena Tavares Rocha, Rachel Kier. Supervisão: Martha Silva de Carvalho. Possivelmente, essa cartilha decorreu de algum projeto específico, o qual ainda não foi identificado na pesquisa.

10 Várias dessas cartilhas/pré-livros e/ou suas autoras foram estudadas no âmbito do Hisales.
} 
Como destacado em conjunto de outros estudos já realizados sobre a temática ${ }^{11}$, as orientações do CPOE e os livros produzidos no estado indicam que o método global de contos predominou por mais de duas décadas no Rio Grande do Sul, evidenciando a circulação de um "modelo" de livro escolar e de uma tendência hegemônica quanto ao método do ensino da leitura, a partir dos anos de 1950, tendo alcançado seu ápice nos anos de 1960 e 1970. Como se destacou, esse período abrange a data de publicação da Céu Azul, o que indica que as autoras também seguiram a mesma orientação ao planejarem o conteúdo, partindo do texto completo, através das historietas, para o ensino da leitura na fase inicial.

Além disso, em outro estudo (PERES, 2014), identificaram-se as influências norte-americanas na produção dessas cartilhas e pré-livros, demonstrando que as autoras gaúchas adaptaram o método e os livros para ensino inicial da leitura e da escrita produzindo materiais que contemplavam os princípios do método global na perspectiva tanto das palavras progressivas quando do conto/historieta. Nesse sentido, o método global, no Rio Grande do Sul, se diferencia em alguns aspectos daquele preconizado e utilizado em Minas Gerais, por exemplo, sob influência de Lucia Casasanta. A principal diferença está em que os pré-livros gaúchos seguiram mais diretamente a orientação do chamado método da word recognition, de base norte-americana, no qual o ensino e os livros não deveriam começar diretamente com historietas, mas com palavras que deveriam ser cuidadosamente escolhidas, rigorosamente controladas e adequadamente repetidas de forma progressiva nas lições (PERES, 2014).

No que se refere ao conteúdo encontrado nas páginas textuais, apesar de ser identificado o método global de contos, notam-se algumas particularidades específicas na Céu Azul em relação a outros livros que utilizam o mesmo processo do ensino inicial da leitura e da escrita. A proposta inicial, como via de regra é o caso de livros que usam essa abordagem, é a apresentação do nome das personagens principais, avançando paulatinamente para a sentença e as historietas; porém, as do pré-livro em análise se diferem em extensão do que comumente se encontra nos demais livros que utilizam narrativas textuais bem menores e que ocupam apenas uma página, por exemplo. No caso de Céu Azul, as historietas, em um total de seis, se estendem por diferentes páginas, formando uma narrativa contínua.

Assim, em conjunto com as imagens, as historietas, embora estejam separadas pela indicação de seus respectivos títulos, não são isoladas e formam uma única narrativa no decorrer de todo livro. Nesse sentido, pode-se dizer que o livro é "temático", cujo assunto é justamente a chegada do homem à Lua. Mulheres atentas ao seu tempo, Rosa Ruschel e Flávia Braun não hesitaram em criar algo inusitado e com uma certa dose de ousadia e criatividade, tomando um acontecimento histórico dos mais significativos para a humanidade e transformando-o em um conteúdo e formato infantis, perceptível nas páginas de Céu Azul.

Dessa forma, como se afirmou, há seis historietas (com títulos diferenciados), mas todas vinculadas entre si, com um enredo único em sequência e sem uma regularidade no tamanho. São elas, em ordem: "A família" (p. 3-9: 7 páginas); "O foguete" (p. 11-20: 10 páginas); "O brinquedo" (p. 21-39: 19 páginas); "A merenda" (p. 41-48: 8 páginas); "O jornal” (p. 49-58: 10 páginas) e "Vamos dormir" (p. 59-67: 9 páginas), sendo que todas começam sempre em uma página ímpar, apenas com o título acompanhado de uma ilustração, e, a partir da página par subsequente é apresentada a historieta, acompanhada de outras ilustrações. Além disso, estão da mesma forma referenciadas no índice pelos títulos, no final do pré-livro. A narrativa textual e visual é focada em cinco personagens: Martinho (o menino), Selene (a menina), o papai, a mamãe, além da cachorrinha Lica. Cabe registrar, ainda, que não existem sessões com atividades nesse pré-livro.

11 Ver, entre outros, Peres e Cézar (2003); Peres e Porto (2004); Peres (2008); Peres (2014); Peres e Ramil (2015). 
O modelo de livro sem atividades, apenas com as lições e cujas personagens eram crianças (sempre um menino e uma menina), suas famílias e seus animais de estimação, advinha das orientações específicas do método, sendo que uma delas era justamente que o livro contemplasse o chamado universo infantil; daí a importância das personagens crianças, suas brincadeiras, seus animais e suas famílias. Além disso, por apresentar enredos com esse modelo, seria mais adequado aplicar aquilo que era fundamental no método: o uso de palavras - no Rio Grande do Sul, chamado também de método de palavras progressivas - cujas ordens e classificação deveria seguir a progressão de substantivos (os nomes das crianças e dos animais de estimação, além das palavras "papai", "mamãe", "bebê" em alguns casos), verbos (as crianças e os animais fazem alguma ação), para que, depois, fossem introduzidos advérbios e artigos, por exemplo.

Ademais, o que se destaca neste pré-livro é o fato de que a narrativa explorada pelas historietas, tanto pelo texto como pelas ilustrações, se baseia em um acontecimento histórico, famoso e de repercussão mundial, como se enfatizou. Não é comum encontrarmos esse tipo de referências em cartilhas, que costumam usar histórias fictícias e, por vezes, consideradas até mesmo triviais, que se repetem e apresentam algumas sutis variações pelos tipos de cenas, personagens e acontecimentos narrados. Nesse caso, manteve-se a lógica da presença das tradicionais personagens e suas aventuras (para atrair o público infantil) e da estrutura narrativa dos contos, associando, contudo, ao momento histórico vivido pela humanidade: o ápice da corrida espacial liderada pelas duas grandes potências bélicas e tecnológicas do momento: Estados Unidos e União Soviética. Tratava-se do "pequeno passo para o homem, mas um grande salto para a humanidade" que adentraria, pelo livro didático e por uma narrativa adaptada à infância, as salas de aula de muitas escolas do período.

\section{A chegada no homem à Lua nas ilustrações de Céu Azul}

O referido acontecimento histórico que foi o mote para a produção do pré-livro em análise, como reiteradamente destacado, foi a chegada do homem à Lua. Evento de grande repercussão mundial, tal fato ocorreu em 20 de julho de 1969. Nesta data, três astronautas - Neil Armstrong, Edwin Buzz Aldrin e Michael Collins, tripulantes do foguete Saturno V (cujo líder da construção era o engenheiro espacial Wernher von Braun), aterrissaram na superfície lunar com o módulo de comando e serviço Columbia pela missão norte-americana conhecida como Apollo 11.

Este fato - que completou 50 anos em 2019 e foi recordado por diversas mídias - foi acompanhado por milhões de espectadores pela televisão, ao vivo, mundo afora, e também foi amplamente noticiado por outros meios de comunicação, como jornais, revistas, rádio etc. Essa conquista é considerada um dos maiores feitos da National Aeronautics and Space Administration (NASA) e ficou marcada pela emblemática frase "Este é um pequeno passo para o homem, mas um grande salto para a humanidade", dita por Armstrong, o primeiro homem a pisar no satélite, ao deixar sua pegada naquele solo, imagem essa que costuma ser identificada e associada ao referido acontecimento até os dias de hoje (NASA, 2019).

Constata-se, então, que o pré-livro Céu Azul foi publicado pela primeira vez pouco mais de um ano depois do ocorrido, o que nos permite pressupor que foi em data bastante próxima, incorporando-se aí, nesse intervalo de tempo, ou seja, entre o dia 20 de julho de 1969 (chegada do homem à Lua) e 31 de dezembro de 1970 (último dia do ano de publicação, que se encontra registrado no pré-livro), todos os processos de concepção, elaboração do conteúdo textual, criação das ilustrações, produção editorial e gráfica necessários na edição, os quais parecem ter acontecido de forma bastante rápida. 
Tudo indica que essa publicação foi resultado de um acordo realizado entre a editora e as autoras, que investiram conjuntamente na produção desse projeto, aproveitando como temática principal o então recente episódio de repercussão mundial. Levando isso em consideração, é possível inferir que se trata de uma publicação produzida e agilizada estrategicamente pela editora, principalmente por fins mercadológicos, valendo-se da esteira da notícia mundial, que era ainda recente e que impactava a sociedade, impressionada com o feito.

Embora, à primeira vista, o título do pré-livro não faça uma alusão explícita à chegada do homem à Lua, remete às aventuras e imaginações criativas das crianças em "viagens intergalácticas". Portanto, ao se conferir a narrativa textual e visual explorada nas páginas, percebe-se a referência direta a esse episódio. Isso é constatado tanto pelas expressões, palavras, frases e historietas utilizadas nos textos como pelos elementos gráficos identificados nas ilustrações. Ao se analisar especificamente essas ilustrações, nota-se que muitas delas remetem às imagens históricas publicadas pelas mídias da época, através de releituras ${ }^{12}$.

As ilustrações são produtos das culturas que as originaram e são desenvolvidas por profissionais com concepções estéticas vinculadas a determinado período. Para além do conteúdo textual, as ilustrações também são suportes que demonstram relações sociais, históricas e ideológicas. Nesse sentido é que a capa do pré-livro Céu Azul contém uma ilustração bastante peculiar, que mostra, sobre o fundo azul escuro, a menina Selene sentada em um foguete amarelo e próximo à Lua, com um capacete na cabeça, segurando a sua boneca Susi, acompanhada de sua cachorrinha Lica ${ }^{13}$. Após a leitura das historietas nas páginas, identificam-se essas referidas personagens e se compreendem os motivos pelos quais a ilustração contém esses elementos representados graficamente, em concordância com a narrativa proposta. Acima dessas personagens, próximo à margem superior da capa, consta o título do pré-livro, em destaque e próximo à Lua (na fase cheia - redonda e amarela), acompanhado dos nomes das autoras, sendo estes em tamanho bem menor e mais discretos, todos na cor branca e com fontes em caixa alta. Já a marca das Edições Tabajara, também na cor branca, está presente no canto inferior direito da capa, abaixo do foguete, o qual parece estar se locomovendo de baixo para cima e da esquerda para a direita, visto que está ilustrado no sentido diagonal, reforçando a ideia de movimento e velocidade na cena narrada visualmente pela ilustração.

Na contracapa, com fundo branco, aparece uma listagem de livros publicados pela editora, impressa na cor preta e organizada em duas colunas, os quais são referenciados como sendo "De acordo com as novas teorias e técnicas de ensino e aprendizagem, com edições especiais para todos os estados do Brasil"14. Essa era uma prática adotada frequentemente pela Tabajara nos seus livros, como estratégia de divulgação de suas publicações didáticas. A Figura 1 mostra a capa e a contracapa com os dados comentados.

12 O termo releitura é utilizado para fazer referência aos casos em que alguém utiliza determinada referência artística (fotografia, pintura, escultura etc.) para, através de uma apropriação dela, propor uma nova produção visual, com a sua reinterpretação, a partir de uma estética própria e diferenciada.

13 Foge ao escopo deste trabalho a análise das questões de gênero do pré-livro. Registra-se, contudo, que há representações de gênero desde a capa até, principalmente, na identificação da família em cenas diversas.

14 É interessante destacar que, na capa e na falsa folha de rosto, foram encontrados registros de um carimbo, repetido três vezes (sendo um na capa, sobre o foguete, para poder ser visualizado), que anuncia: "Delegacia do Ensino Básico de Rio Claro - Setor Regional de Orientação Pedagógica". Esse município está situado no estado de São Paulo, o que comprova que o pré-livro, mesmo sendo de origem gaúcha (pela sua autoria e edição), foi enviado para instituições de fora do estado do Rio Grande do Sul e quiçá usado em escolas de outros estados. Além disso, há um outro carimbo que anuncia: "Oferta da editora - não pode ser vendido", repetido na falsa folha de rosto e na folha de rosto, com o qual se entende que o livro também foi fornecido gratuitamente às escolas para promoção dessa publicação nas instituições vinculadas à educação. 
Figura 1 - Capa (à esquerda) e contracapa (à direita) do pré-livro Céu Azul.
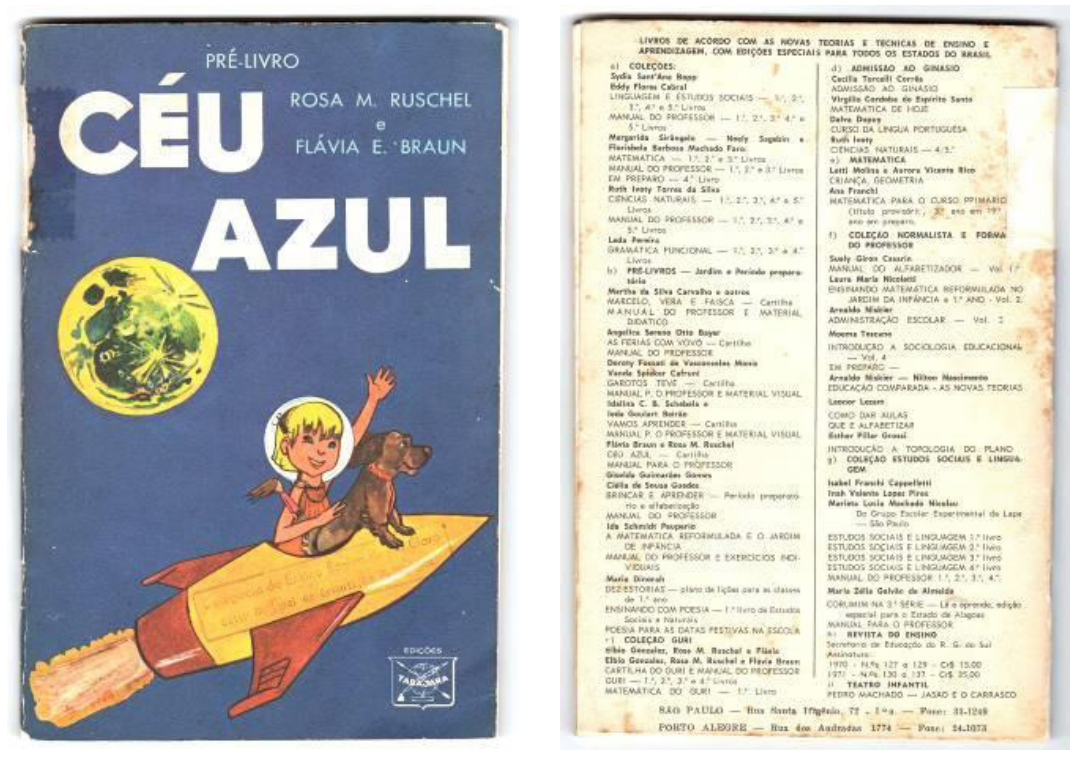

Fonte: Ruschel e Braun (1970).

Além da ilustração da capa, há 63 ilustrações no miolo do pré-livro, todas coloridas, com contorno em preto e preenchimento de cores variadas. Elas estão posicionadas separadamente, sendo uma em cada página, sempre acima da historieta, em grandes dimensões, e demonstram uma sequência de imagens que indicam uma narrativa visual que representa graficamente o enredo proposto. O texto é apresentado com tipografia de fontes do tipo bastão e sem serifas, na cor preta, e está posicionado na base das páginas, sempre alinhado à esquerda.

No que se refere à narrativa textual explorada pelas historietas, alguns exemplos de excertos destacados das páginas e que tratam sobre o episódio da chegada do homem à Lua podem ser conferidos no Quadro 1:

Quadro 1 - Excertos das historietas no pré-livro Céu Azul, que tratam sobre o episódio da chegada do homem na Lua.

\begin{tabular}{|c|c|}
\hline Página & Excerto das historietas - pré-livro Céu Azul \\
\hline p. 12 & "[...] O foguete sobe. O foguete sobe... sobe..." \\
\hline p. 13 & "O foguete sobe. O foguete sobe alto. — Que fumaça! - diz Selene." \\
\hline p. 14 & "[...] O foguete sobe alto, alto. O foguete vai longe. O foguete vai à Lua." \\
\hline p. 15 & "Papai diz: — O homem vai à Lua. Êle vai no foguete. A Lua fica longe... Ionge..." \\
\hline p. 16 & "Martinho grita: - Vamos à Lua! Vamos à Lua! — Não! Ainda não! - diz papai." \\
\hline p. 17 & "-Olhe o astronauta, Martinho. Olhe o astronauta, Selene. Êle pode ir à Lua." \\
\hline p. 51 & "[...] — Papai! Papai! Olhe aqui. Aqui no jornal diz: O homem chegou à Lua!" \\
\hline p. 52 & "[...] Selene lê outra vez: - O homem chegou à Lua -" \\
\hline p. 53 & "[...] — Homens na Lua? — Sim! diz papai. Os homens chegaram à Lua! Olhem as fotos." \\
\hline p. 54 & "[...] — Mamãe! Mamãe! Veja as fotos da Lua. Veja as fotos dos astronautas." \\
\hline p. 55 & "[...] Vejam as crateras da Lua! Na Lua há muitas crateras. Elas são grandes e pequenas." \\
\hline p. 56 & "- Vejam! Vejam! O astronauta está na Lua. O astronauta olha... olha... Êle olha as pedras da Lua." \\
\hline p. 57 & $\begin{array}{l}\text { "Aqui estão as marcas. As marcas são das botas. O astronauta caminhou muito. Êle deixou } \\
\text { marcas na Lua". }\end{array}$ \\
\hline
\end{tabular}


Considerando o conteúdo exposto, exemplificado pelos excertos mostrados, além do restante das historietas e do que indicam as ilustrações no decorrer das páginas, de acordo com o desenvolvimento da narrativa, o tema do homem na Lua aparece, pelo menos, em quatro contextos, tanto textual como visual: nas conversas da família, na cena em que a família assiste ao evento na televisão, nos jornais mostrados e lidos entre pais e filhos e também nas brincadeiras das crianças Martinho e Selene.

No que diz respeito às ilustrações, amparou-se no processo do método iconológico de leitura de imagens, utilizado por Panofsky (1986), como já destacado. Segundo o autor, uma imagem possui forma, tema e conteúdo, e, para este entendimento, há três fases de leituras, quais sejam: a leitura pré-iconográfica, pela qual se verifica a forma da imagem; a leitura iconográfica, na qual se identifica o tema; e a leitura iconológica, para se analisar o conteúdo.

Sendo assim, pela primeira fase - pré-iconográfica, faz-se a descrição de aspectos das ilustrações das páginas (além da capa supracitada), pela sua forma e sem atribuição de valores e especificidades, tais como os desenhos das personagens Martinho (o menino), Selene (a menina), o papai, a mamãe e a cachorrinha Lica, além dos ambientes do interior de uma casa, com os referidos móveis. As ilustrações ocupam bastante espaço nas páginas (na parte superior do texto), não há molduras delimitando, o que torna as imagens mais livres no espaço e, em algumas delas, percebe-se uma ideia de continuidade, pois há partes justapostas às margens do suporte. Os elementos gráficos representados possuem contorno preto e livre, remetendo a um traçado dinâmico de nanquim e variadas cores são utilizadas em seu preenchimento, de forma uniforme e chapada, em geral, sendo que algumas tonalidades aparecem com mais recorrência pela repetição dos elementos, como o vermelho do vestido de Selene. Além disso, reconhece-se a fisionomia, o tom de pele e a cor dos cabelos das personagens. Ao redor, no fundo ou na base dessas cenas, são usadas para suporte ou agrupamento das formas algumas manchas orgânicas representando o chão, a parede, o céu, entre outros, criadas com uma técnica que remete à pintura de aquarela, pelas suas características plásticas.

Já na fase iconográfica, é importante entender os temas abordados nas ilustrações, considerando a narrativa, os símbolos, as convenções e as alegorias que constam nessas imagens. Com isso, observa-se que todos esses elementos nos mostram cenas de uma família composta por pai, mãe e dois filhos (a menina e o menino, que parecem ter pouca diferença de idade entre si), nas quais se observam os papéis de cada personagem e como se relacionam, posicionam e interagem entre si em variados momentos, como na hora da conversa, da reunião em família, do lazer, da brincadeira, da merenda, no acompanhamento das notícias pelo jornal e pela televisão, além de perceberem-se hábitos, afetividade, rituais, ações do dia-a-dia etc. Trata-se da representação de uma família branca de classe social média, perceptível pelos elementos e pela caracterização dos cenários e também pelo acesso a aparelhos eletrônicos e sua inserção no contexto da modernização e do avanço da tecnologia à época, por exemplo. Alguns itens ilustrados, por seus significados e simbologias, podem ser associados também a outros fatores específicos, como é o caso da representação do capacete, do foguete e do astronauta, que nos remetem ao espaço, à astronomia, aos planetas e à Lua.

Por fim, na fase iconológica, para ampliar a percepção e realizar a interpretação das ilustrações como um todo, exploram-se as características culturais, a mentalidade, a motivação e as intencionalidades das cenas e elementos ali representados, além do contexto social, econômico e histórico que essas imagens retratam. Com isso, identificou-se a proposta da narrativa visual mostrando a rotina de uma família, acrescida de um fato histórico, o da chegada do homem à Lua, devido aos detalhes observados nas páginas, que serão comentados na sequência deste texto com algumas exemplificações. 
As ilustrações apresentam qualidade estética que pode ser associada ao período entre os anos de 1960 e 1970 pelas características de expressão gráfica dos objetos, personagens e cenas representados, como, por exemplo, no desenho e formato das roupas (vestido e sapatilhas de Selene, short e sapatos de Martinho, roupa e faixa de cabelo da mãe, roupa do pai etc.), cabelos (estilo de penteado das personagens), modelos de mobiliários (mesa para televisão, suporte de vaso de plantas, poltrona, cama etc.), versões de aparelhos eletrônicos (televisão e antena, gravador de fita cassete, etc.), brinquedo (boneca Susi), utensílios e hábitos (cruz pendurada em cima da cabeceira da cama da criança, suporte para xícara de "cafezinho", canudos no copo de refresco com gelo na merenda), entre outros que remetem àqueles comumente identificados por serem utilizados entre as referidas décadas. Nota-se que as ilustrações, pela sua expressividade, destaque nas páginas e forma como foram construídas as cenas, são potentes e sustentam, por si só, uma narrativa visual compreensível, e não necessariamente dependem das historietas para serem interpretadas. Mesmo assim, as narrativas textual e visual se complementam significativamente, e as historietas, pelas informações que apresentam, se relacionam com as ilustrações e vice-versa.

Ademais, a ilustradora procurou fazer releituras de imagens bastante recorrentes e conhecidas que costumam ser associadas ao episódio do homem na Lua, o que enfatiza ainda mais a temática adotada pela Céu Azul. Isso proporcionaria que as pessoas, no caso em especial as alunas e alunos nas salas de aula, pudessem reconhecer essas imagens (tendo vivenciado ou não o evento naquela época) e estabelecessem o vínculo e as demais, que porventura desconhecessem, sejam elas crianças, jovens ou adultos, tivessem a oportunidade de conhecer e visualizar uma interpretação em específico sobre esse evento histórico não fictício, por meio da representação textual e visual proposta no pré-livro. Por isso, esse artefato pedagógico acabaria, então, provocando uma ressignificação, não apenas a partir das imagens consideradas clássicas, mas do acontecimento histórico como um todo.

As imagens das quais várias ilustrações do pré-livro se originam são fotografias, cenas de filmagens congeladas e exemplares de imprensa, como jornais e revistas, que foram também reinterpretadas inúmeras vezes desde então por distintos métodos gráficos, suportes variados e com finalidades diversas pelo mundo afora. Por serem tão divulgadas, essas fotografias tornaram-se referências facilmente reconhecidas, devido à sua recorrência e sua associação ao referido fato histórico. Ademais, segundo Kossoy (1989, p. 33):

Toda fotografia é um testemunho segundo um filtro cultural, ao mesmo tempo em que é uma criação a partir de um visível fotográfico. Toda fotografia representa o testemunho de uma criação. Por outro lado, ela representará sempre a criação de um testemunho.

Dessa forma, na Céu Azul, foram identificadas dez ilustrações que são plausíveis de associação às imagens fotográficas que registram o evento da chegada do homem à Lua e se tornaram, de alguma forma, testemunhas deste acontecimento histórico, sendo que quatro delas, mais especificamente, podem ser consideradas releituras de imagens bastante conhecidas, devido à sua exposição na mídia na época e no decorrer dos anos. Além disso, outras ilustrações, apesar de não serem explícitas por si só e não evidenciarem especificamente uma referência ao episódio, podem ser interpretadas junto ao enredo de seus textos, reforçando o desenvolvimento da narrativa textual e visual das historietas. 
Entre as ilustrações identificadas como sendo de associação mais direta ao fato histórico, em geral, elas mostram as seguintes representações: a família assistindo, na sala, à chegada do homem à Lua pela televisão; o foguete indo em direção à Lua; o astronauta caminhando na Lua; crateras da Lua; o pai lendo um jornal com a manchete "O homem no espaço" em uma página e, em outra, há um fragmento de título que não aparece completo, mas no qual é possível ler "A conqui[...]", o que provavelmente deveria querer representar a palavra "conquista"; as protagonistas, Martinho e Selene, vendo a imagem das crateras da Lua em uma página de jornal; as crianças, Martinho e Selene, lendo um jornal com a manchete "O homem na Lua" e um trecho que diz "O maior [...]" abaixo da imagem do astronauta; a marca das pegadas dos pés do astronauta na Lua; entre outros (RUSCHEL; BRAUN, 1970).

Burke (2004) defende que as imagens são testemunhos da história. Para o autor, "uma vantagem particular do testemunho de imagens é a de que elas comunicam rápida e claramente os detalhes de um processo complexo que um texto levaria muito mais tempo para descrever, e de forma mais vaga [...]" (BURKE, 2017, p. 125). Na Figura 2, mostra-se, à direita, uma fotografia que representa o que aconteceu naquele dia 20 de julho de 1969, exemplificando a famosa cena da inédita caminhada do astronauta pela superfície lunar e, à esquerda, nota-se que a ilustradora representou esse mesmo momento em uma página de jornal que está sendo lida pelas crianças, Selene e Martinho, cuja manchete é "O homem na Lua". Vale lembrar que muitos jornais da época anunciaram o acontecimento com manchetes iguais às encontradas nas ilustrações ou bastante parecidas, destacando o acontecimento inédito para a história da humanidade.

Figura 2 - À esquerda: página do pré-livro Céu Azul, com ilustração do astronauta em uma página de jornal, em matéria com manchete "O homem na Lua";

à direita: fotografia da caminhada do homem (astronauta) na Lua.
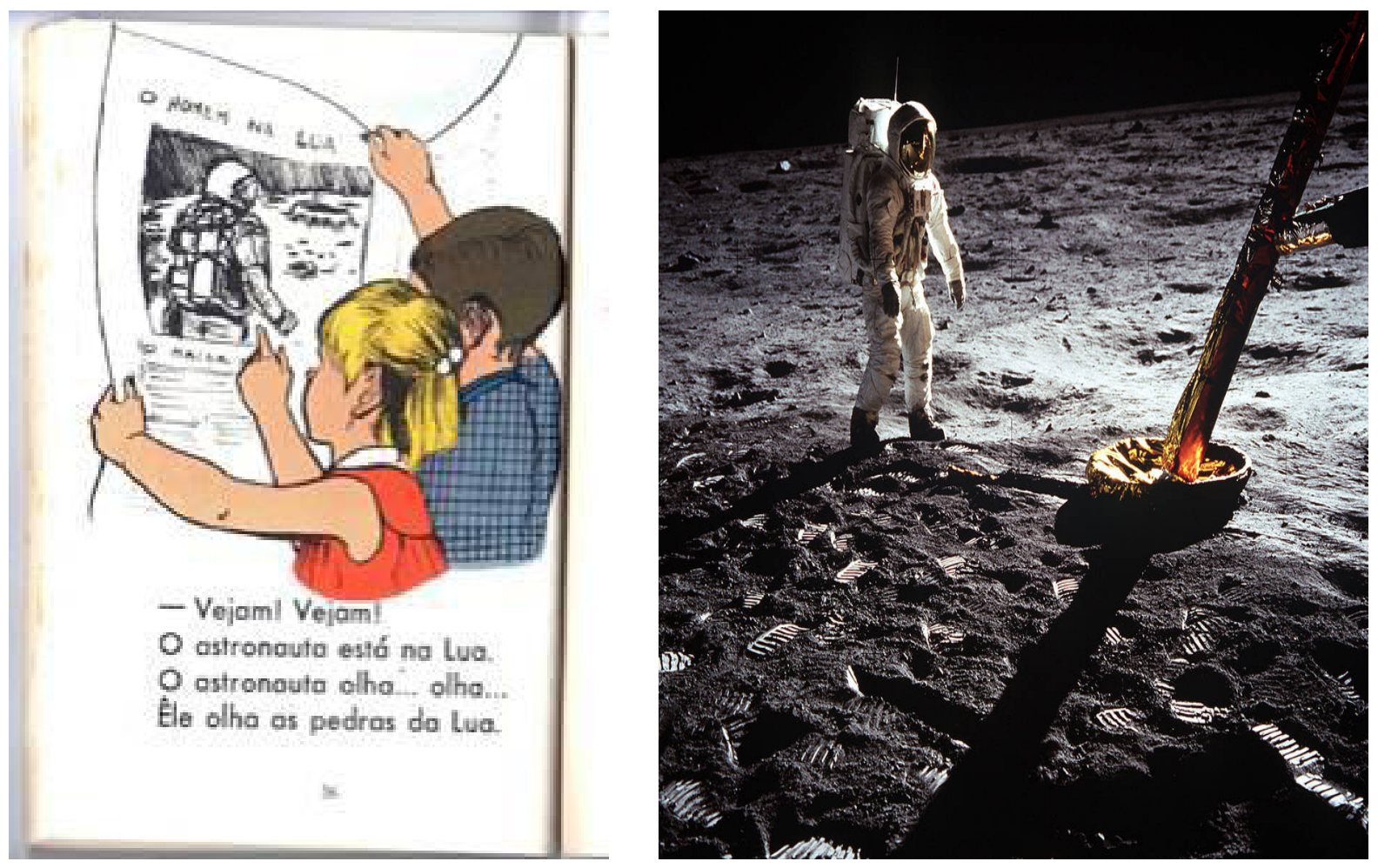

Fonte: À esquerda: Ruschel e Braun (1970, p. 56); à direita: Fotos Públicas (2021). 
Existem fotografias que ficam marcadas na história ao registrarem determinado momento. Sobre isso, Samain (2012) afirma que as fotografias fixam o espectador num congelamento do tempo no mundo e convidam-no a entrar na espessura de uma memória. A Figura 3 demonstra isso, visto que, à direita, consta a fotografia com a marca da pegada da bota do astronauta no solo lunar, que se tornou um ícone mundial e que, até hoje, ao mobilizar a nossa memória, pode ser associada ao que se costuma dizer: "quando o homem pisou pela primeira vez na Lua", mesmo que alguém não tenha assistido ao episódio em tempo real pela televisão ou conferido os registros posteriores nas mídias impressas. Essa fotografia, tão potente visualmente e significativa desse fato histórico, foi ressignificada na ilustração em uma das páginas do pré-livro, conforme pode ser visto, à esquerda na mesma figura.

Figura 3 - À esquerda: página do pré-livro Céu Azul, com ilustração da marca das pegadas do astronauta, ao pisar na Lua; à direita: uma das fotografias com o registro dessa ação no solo lunar.
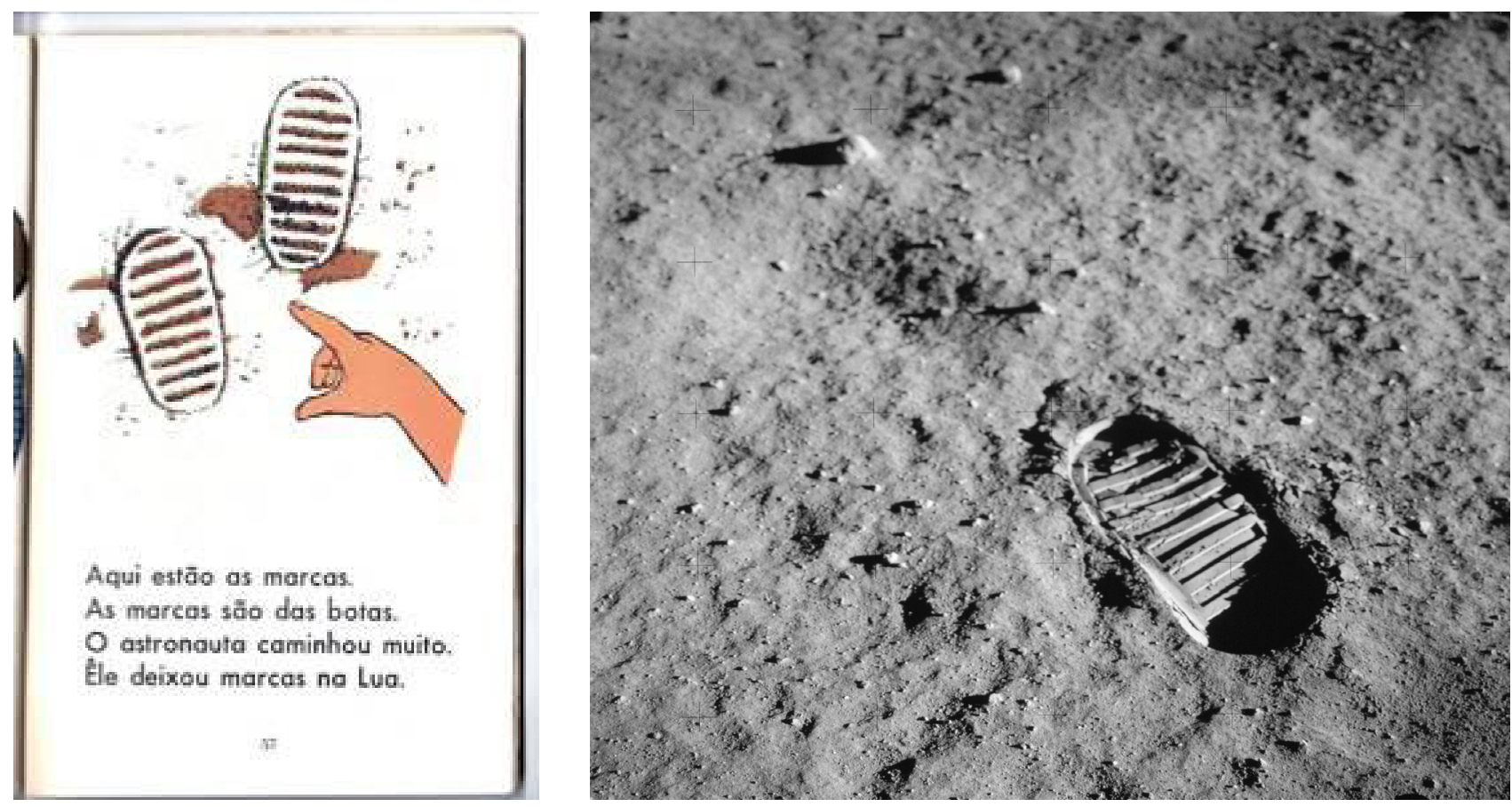

Fonte: À esquerda: Ruschel e Braun (1970, p. 57); à direita: Fotos Públicas (2021).

Sabe-se que os anos de 1960 e 1970 representaram, nacional e internacionalmente, mudanças políticas, culturais, sociais, tecnológicas, de comportamento e de valores. Entretanto, igualmente e contraditoriamente, representou a continuidade e a manutenção de uma mentalidade vigente no que tange especialmente à família e aos papéis sociais de homens e de mulheres. Nesse âmbito, percebe-se que essa noção também é veiculada no pré-livro Céu Azul, reforçando e perpetuando determinadas visões de mundo, ao mesmo tempo que trata da chegada do homem à Lua. Por isso, as imagens, nesse caso, as ilustrações,

[...] não são um reflexo da realidade social nem um sistema de signos sem relação com a realidade social, mas ocupam uma variedade de posições entre esses extremos. Elas são testemunhas dos estereótipos, mas também mudanças graduais, pelas quais indivíduos ou grupos vêem o mundo social, incluindo o mundo de sua imaginação (BURKE, 2004, p. 232). 
Nesse sentido, a Figura 4 mostra um exemplo no qual, ao mesmo tempo em que a ilustração identifica e detalha o acontecimento histórico da chegada do homem na Lua sendo ressignificado na página do jornal, mostra também a típica cena em que o pai engravatado, vestindo camisa e calça social, está sentado na poltrona e lendo um periódico, aguardando o "cafézinho" que está sendo levado pela sua pequena filha Selene. Vale ressaltar que há seis ilustrações com a mesma personagem sentada no mesmo móvel, em ângulos diversificados e com algumas variações na cena, como a presença da família ao seu redor na sala de casa, o que também era bastante recorrente de se encontrar em ilustrações representativas de famílias nas páginas das cartilhas e dos pré-livros publicados naquele período.

Figura 4 - Páginas do pré-livro Céu Azul ilustrando a cena da filha Selene levando um "cafezinho" ao pai e ele, em sua poltrona, lendo uma página de jornal com a notícia de manchete

"O homem no espaço", ilustrada com a cena do astronauta na Lua.

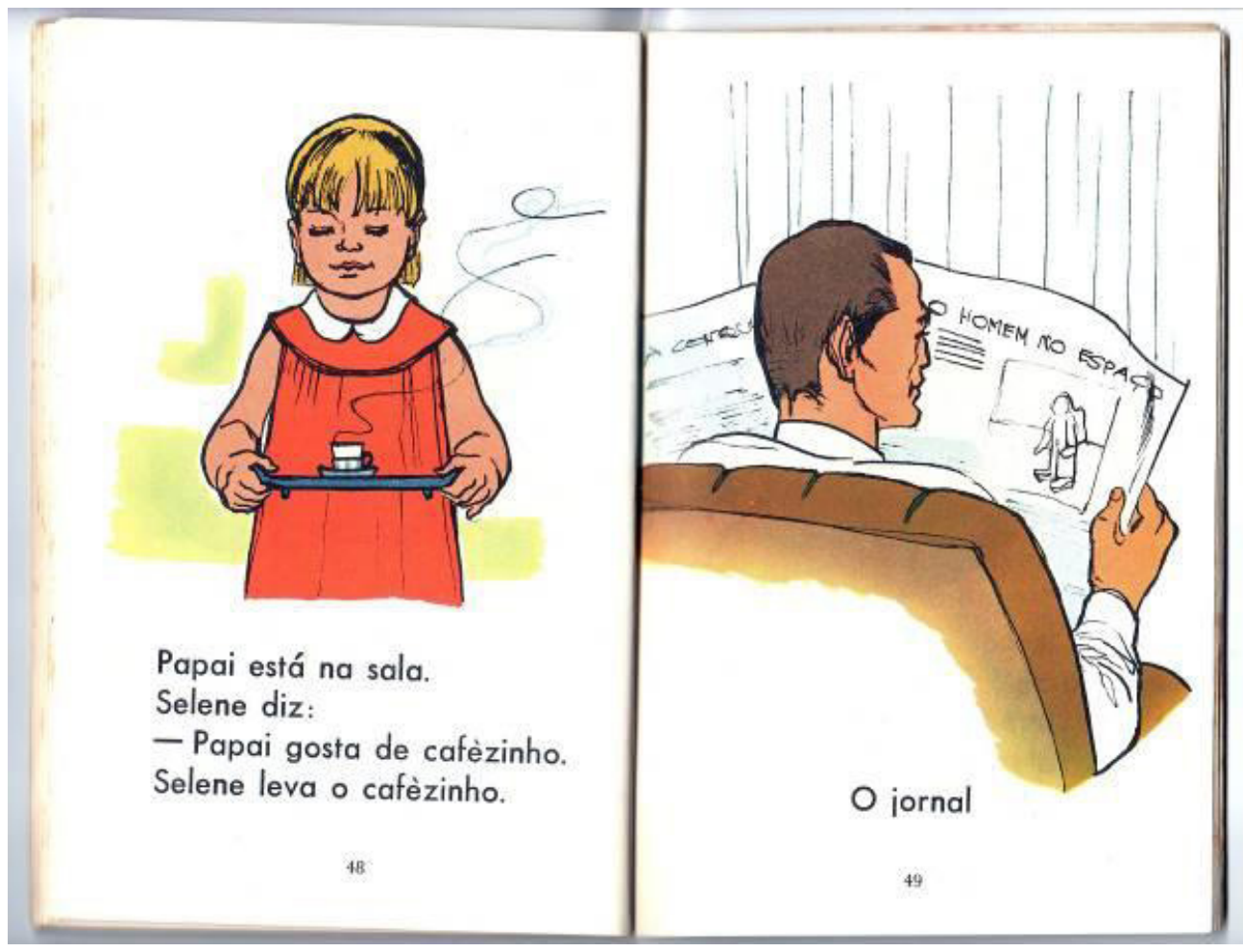

Fonte: Ruschel e Braun (1970, p. 48-49).

Exemplos de ilustrações como essas denotam que esses modelos de família são comumente replicados visualmente em livros didáticos e atrelados a aspectos ideológicos vinculados aos preceitos de um determinado período. Nesse caso, embora o tema seja inusitado, trazendo ao universo infantil "o acontecimento do século", as representações de família mantiveram-se relacionadas à cosmovisão do período em que o pré-livro Céu Azul foi produzido.

Também há três ilustrações que representam a cena em que as famílias assistem pela televisão à chegada do homem à Lua. Naquele dia, muitas cidades pararam para acompanhar aquele que foi considerado o grande acontecimento do século, com famílias reunidas ao redor da televisão, a qual ainda era em preto e branco no Brasil, ou mesmo escutando pelo rádio, por exemplo. Ao se observar imagens como essas, pode-se compreender como as "imagens podem auxiliar a posteridade a se sintonizar com a sensibilidade coletiva de um período passado" (BURKE, 2017, p. 51). 
Quiçá, as autoras, a ilustradora e a editora pretendiam sintonizar e sensibilizar as crianças, aprendizes da leitura e da escrita, para um momento, uma realidade, um contexto em especial em que se confrontavam, pelo menos desde os anos de 1950, com a chamada Guerra Fria, as duas potências mundiais: Estados Unidos e União Soviética. A escolha do tema, das ilustrações e a construção da narrativa não foi mero acaso pedagógico ou didático, senão que se atrelavam a uma perspectiva social e ideológica e com intencionalidades de/na formação dos escolares.

Ainda em relação aos registros fotográficos, além do vínculo ao fato histórico, é possível encontrar elementos que caracterizam a sociedade, a relação familiar, a cultura, os hábitos e os produtos da época. Por isso, as "[...] fotografias podem ser consideradas ambas as coisas: evidência da história e história. Elas são especialmente valiosas, por exemplo, como evidência da cultura material do passado" (BURKE, 2017, p. 40).

Na Figura 5, à direita, consta um exemplo desse momento, retratado por uma fotografia tirada no mesmo dia em que o homem pisava na Lua; à esquerda, mostra-se uma das ilustrações criadas especificamente sobre esse momento para o pré-livro, incluindo na cena o papai, a mamãe, os filhos Selene e Martinho e também a cachorrinha Lica. Pela leitura das imagens, observa-se que tanto na fotografia como na ilustração, principalmente no que se refere aos elementos, objetos e modelos sociais exemplificados em ambas as cenas, é possível identificar a semelhança das características determinantes do contexto daquela época, bem como das práticas realizadas em família para acompanhamento daquele evento histórico. Nota-se que, nas duas imagens, está representada uma família constituída por pessoas de várias faixas etárias sentadas diante da televisão que fica na sala e que transmite o acontecimento ao vivo. Vale lembrar que essa mesma cena teria se repetido em milhares de lares. Além disso, independentemente da relação observada com o fato ocorrido em 1969, os estilos de móveis e as versões de televisão, além das roupas e penteados das pessoas representadas nas imagens e a forma como se comportam e se posicionam permitem que estas sejam relacionadas a um recorte temporal, levando-se em consideração também o contexto histórico, social e cultural da época, ou seja, a representação de um dado momento histórico.

Figura 5 - À esquerda: página do pré-livro Céu Azul ilustrando a cena da família que assiste à chegada do homem à Lua; à direita: fotografia com o registro do mesmo momento.
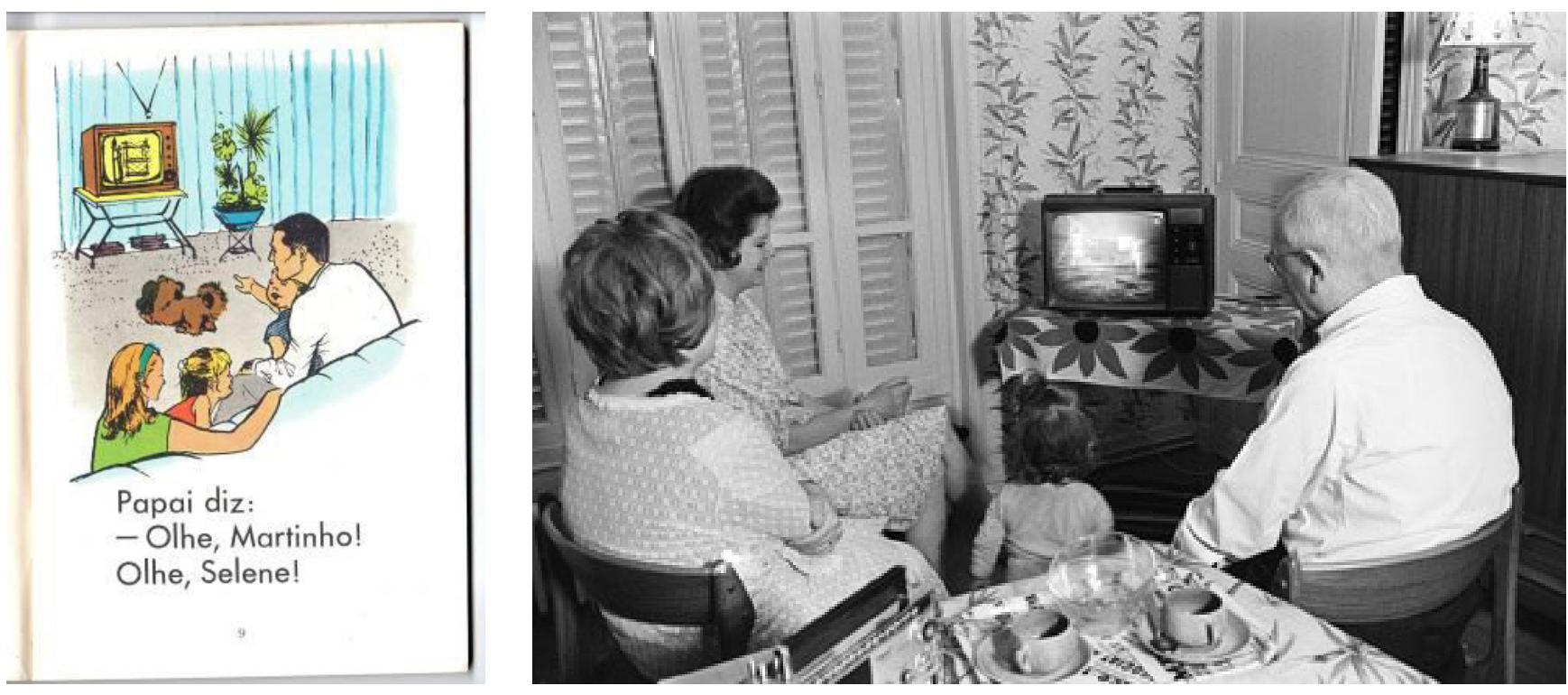

Fonte: À esquerda: Ruschel e Braun (1970, p. 9); à direita: Costa (2019). 
Além disso, ainda em relação à cultura material do período retratado, uma das páginas, ao mostrar a personagem Selene brincando de astronauta com um capacete na cabeça, cita - textual e visualmente - a boneca Susi, lançada em 1966 no Brasil pela fábrica de brinquedos Estrela, reforçando o vínculo ao contexto mercadológico e lúdico das crianças de determinados grupos sociais daquele momento. A mesma boneca, que foi um sucesso de venda para a infância - pelo menos a uma infância específica - daqueles anos, também está na capa do pré-livro e aparece sendo segurada pela personagem Selene, que está sentada no foguete, como se destacou anteriormente. A Figura 6 mostra a referida página, à esquerda, e exibe uma das propagandas da boneca citada, à direita.

Figura 6 - À esquerda: página do pré-livro Céu Azul, com texto e ilustração em referência à boneca Susi, junto à personagem Selene; à direita: fotografia de propaganda da boneca Susi, de 1970.
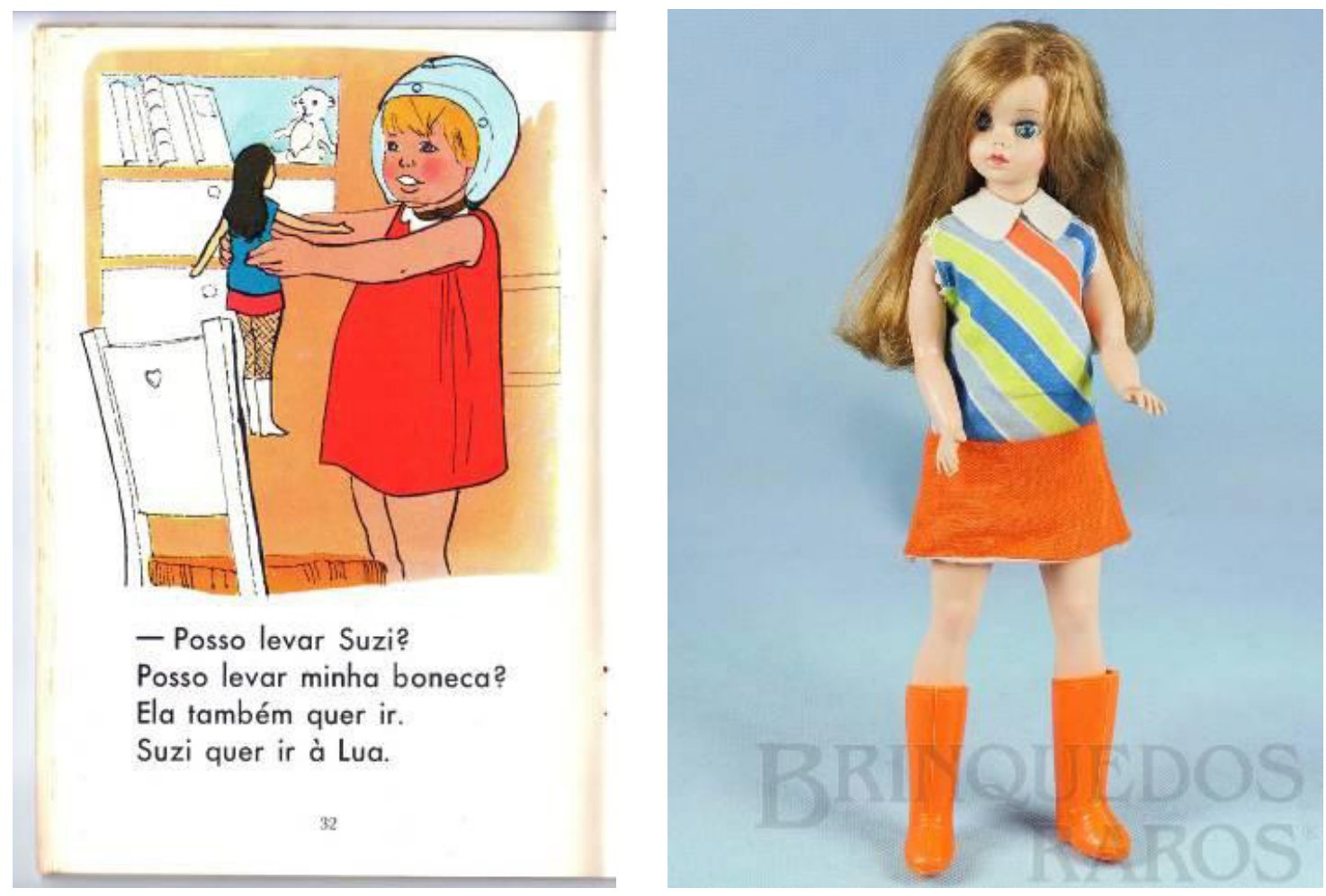

Fonte: À esquerda: Ruschel e Braun (1970, p. 32); à direita: Brinquedos Raros (2021).

Considerando os exemplos apresentados - e o conjunto da obra em análise - pode-se dizer que, do ponto de vista da iconografia, identificaram-se os elementos presentes nas ilustrações e, com isso, revelaram-se as características expressivas de uma determinada época, qual seja, o período compreendido entre as décadas de 1960 e 1970. Além disso, também se interpretaram as relações representadas nas cenas com o reconhecimento da temática norteadora, das motivações, ideias, referências e simbologias envolvidas nas historietas que apresentam o dia-a-dia de uma família, mas que, nesse caso, sua narrativa apresenta um diferencial ao explorar e se apropriar de um fenômeno real acontecido pouco tempo antes, a chegada do homem à Lua, em 1969. Em relação à iconologia, o estudo do pré-livro Céu Azul mostra o significado dessa obra didática e o que evidenciam as suas ilustrações, no que se refere ao interesse pela demonstração daquele episódio, às escolhas das imagens e suas especificidades, às intenções da editora, autoras e ilustradora, além de constatarem-se aspectos do contexto cultural, histórico, econômico e social, os valores ideológicos e simbólicos, bem como a percepção das estratégias didáticas, editoriais e mercadológicas na qual o pré-livro estava inserido. 


\section{Considerações finais}

Para finalizar, reafirma-se que as imagens também podem ser fonte de evidência (BURKE, 2017) para pesquisadoras(es) e historiadoras(es), especialmente no intuito de compreender, de um outro ponto de vista, narrativas de um determinado tempo e espaço. Para o caso da história da educação, essas imagens permitem, entre outras observações, identificar como chegam e circulam no espaço escolar e como "educam" visualmente alunos e alunas. No que se refere aos seus usos em livros didáticos, trata-se, como o caso estudado revela, de uma dimensão que não é apenas "decorativa". As ilustrações, associadas ao texto escrito, compõem uma narrativa que apresenta visões de mundo que se quer construir e impor às novas gerações.

Nesse sentido, um livro didático nunca é um produto neutro e imparcial. Como um artefato de seu tempo, Céu Azul revela as relações entre o mercado editorial didático, a sala de aula, os acontecimentos históricos e as intencionalidades sociais e pedagógicas. O pré-livro analisado é um exemplo de que a produção didática, em especial os livros, resultam de um conjunto de variáveis que estão associadas tanto aos ordenamentos pedagógicos, quanto aos políticos, culturais, sociais e econômicos. A década de 1970, em especial seu primeiro ano, foi o momento ideal para que a Editora Tabajara - uma empresa atenta ao seu tempo - lançasse um livro para ensino da leitura com uma temática que, além de possivelmente chamar a atenção dos alunos e alunas, poderia despertar interesse no mercado como um todo.

Assim, pode-se afirmar que produzir um pré-livro para o ensino da leitura e da escrita na sequência de um acontecimento que impactaria significativamente a humanidade, como o caso da chegada no homem à Lua, foi uma estratégia mercadológica da editora, associada à dimensão didático-pedagógica: a ideia era também que tal temática, inusitada e moderna, agradasse e despertasse a curiosidade do público-alvo, qual seja, as crianças em fase de aprendizagem da leitura e da escrita. À procura de temas motivadores, agradáveis e atraentes para as crianças, as "aventuras galácticas" e, em especial, o maior feito do homem na sua relação com o espaço, a chegada à Lua, foram, possivelmente, consideradas pela editora, autoras e ilustradora um mote adequado, instigante e extraordinário à finalidade de produzir narrativas atraentes para alfabetizar.

Estima-se que mais de mais de 600 milhões de pessoas no mundo inteiro assistiram ao espetáculo da chegada do homem à Lua, ao vivo, pela TV, em mais de 33 países, o que marcaria a era das transmissões via satélite, inclusive no Brasil (CHEGADA..., 2021). O impacto de tal acontecimento e da transmissão disso para diferentes países certamente marcou a geração dos anos de 1960. Tratava-se, também, de um resultado importante para os Estados Unidos em relação à corrida espacial com a União Soviética. Não por acaso, como se mostrou, as ilustrações foram releituras de imagens que circularam socialmente nos meios de comunicação impressos e televisivos. As autoras e a editora, como sujeitos sociais de seu tempo, expressaram, no pré-livro, em forma de uma narrativa para a infância a importância desse feito. Além disso, construíram um enredo - associando textos e ilustrações - de modernidade, de avanço, de tecnologia, da ciência, de novos tempos, embora, como se destacou, a família foi apresentada em uma perspectiva única, a de família nuclear, como todos as cartilhas e pré-livros produzidos no Rio Grande do Sul e quiçá no Brasil, naquele período, com papéis específicos desempenhados por cada um de seus integrantes. Mas talvez a contradição estivesse posta: não deve ter sido por acaso que Selene, a mesma que serve o café ao pai quando ele chega do trabalho e acomoda-se confortavelmente na poltrona para ler o jornal, é também a personagem retratada na capa, ao invés de Martinho, que, sob um céu azul, pilota um foguete. Há, para dizer o mínimo, uma representação significativa nessa escolha de ilustração: poderia Selene ser uma astronauta? 
Para finalizar, reafirma-se que a chegada do homem à Lua foi o tema apropriado para fazer chegar às crianças - alunos e alunas das escolas gaúchas, principalmente - e às professoras - quiçá, mulheres modernas - um discurso de que os tempos haviam mudado, de que as famílias - mas ainda pai, mãe, dois filhos, o menino, a menina e o cachorro - estavam atentas aos avanços da sociedade, às conquistas da tecnologia e da supremacia norte-americana. Todos precisavam reconhecer que havia sido "um pequeno passo do homem, mas um grande salto para a humanidade", afinal, os livros para o ensino da leitura e da escrita iniciais - primeiro artefato usado no início da escolarização das crianças, especialmente naquele momento - também deveriam ensinar modelos a serem seguidos.

\section{Referências}

ARAÚJO, Emmanuel. A construção do livro. Rio de Janeiro: Nova Fronteira, 1986.

BATISTA, Antônio Augusto Gomes. Um objeto variável e instável: textos, impressos e livros didáticos. In: ABREU, Márcia (org.). Leitura, História e História da Leitura. Campinas: Mercado das Letras, 1999. p. 529-575.

BITTENCOURT, Circe Maria Fernandes. Livro didático e saber escolar (1810-1910). Belo Horizonte: Autêntica, 2008. BRINQUEDOS RAROS, 2021. Disponível em: https://www.brinquedosraros.com.br. Acesso em: 20 set. 2021.

BURKE, Peter. Testemunha ocular. História e Imagens. Bauru: Edusc, 2004.

BURKE, Peter. Testemunha ocular. O uso das imagens como evidência histórica. São Paulo: UNESP, 2017.

CHEGADA do Homem à Lua. Memória Globo, 2021. Disponível em: https://memoriaglobo.globo.com/jornalismo/ coberturas/chegada-do-homem-a-lua/. Acesso em: 12 set. 2021.

COSTA, José Roberto V. Um brasileiro na Lua. Astronomia no Zênite, 19 jul. 2019. Disponível em: https://www. zenite.nu/um-brasileiro-na-lua. Acesso em: 20 set. 2021.

DARNTON, Robert. "O que é a história do livro?" revisitado. ArtCultura, Uberlândia, v. 10, n. 16, p. 155-169, jan./ jun. 2008.

DARNTON, Robert. O beijo de Lamourette: mídia, cultura e revolução. São Paulo: Companhia das Letras, 2010.

ESCOLANO BENITO, Agustín. A escola como cultura: experiência, memória, arqueologia. Tradução de Heloísa Helena Pimenta Rocha e Vera Lucia Gaspar da Silva. Campinas: Alínea, 2017.

FOTOS PÚBLICAS. Os 50 anos do primeiro homem na Lua, 2021. Disponível em: https://fotospublicas.com/os50-anos-do-primeiro-homem-na-lua/. Acesso em: 12 set. 2021.

KOSSOY, Boris. Fotografia e história. São Paulo: Editora Ática, 1989.

MACIEL, Francisca Isabel Pereira. Lúcia Casasanta e o método global de contos: uma contribuição à história da alfabetização em Minas Gerais. 2001. 179 f. Tese (Doutorado em Educação) - Programa de Pós-Graduação em Educação, Faculdade de Educação, Universidade Federal de Minas Gerais, Belo Horizonte, 2001.

MUNAKATA, K. Produzindo livros didáticos e paradidáticos. 218 f. Tese (Doutorado em História e Filosofia da Educação) - Pontifícia Universidade Católica de São Paulo, São Paulo, 1997.

NATIONAL AERONAUTICS AND SPACE ADMINISTRATION (NASA). 2019. Disponível em: https://www.nasa. gov/. Acesso em: 15 ago. 2019.

PANOFSKY, Erwin. Iconografia e Iconologia: Uma introdução ao estudo da arte da Renascença. In: PANOFSKY, Erwin. Significado nas artes visuais. Tradução: Maria Clara F. Kneese e J. Guinsburg. 2 ed. São Paulo: Perspectiva, 1986. p. 47-65.

PENNEL, Mary E.; CUSACK, Alice M. Como se ensina a leitura. Tradução: Anadyr Coelho. Porto Alegre: Globo, 1935. 
PERES, Eliane. Aprendendo formas de pensar, de sentir e de agir a escola como oficina da vida: discursos pedagógicos e práticas escolares da escola pública primária gaúcha (1909-1959). 2000. 506 f. Tese (Doutorado em Educação) - Programa de Pós-Graduação em Educação, Faculdade de Educação, Universidade Federal de Minas Gerais, Belo Horizonte, 2000.

PERES, Eliane. O ensino da linguagem na escola pública primária gaúcha no período da renovação pedagógica (1930-1950). In: PERES, Eliane; TAMBARA, Elomar (org.). Livros escolares e ensino da leitura e da escrita no Brasil (séculos XIX-XX). Pelotas: Seiva Publicações, 2003.

PERES, Eliane. Autoras de obras didáticas e livros para o ensino da leitura produzidos no Rio Grande do Sul: contribuições à história da alfabetização (1950-1970). Educação Unisinos, São Leopoldo, v. 12, p. 111-121, 2008.

PERES, Eliane. Influências do pensamento norte-americano na produção de cartilhas para o ensino da leitura e da escrita no Rio Grande do Sul na década de 1960. In: MORTATTI, Maria do Rosário Longo; FRADE, Isabel Cristina Alves da Silva (org.). História do ensino de leitura e escrita, métodos e material didático. Marília: UNESP, 2014. p. 93-120.

PERES, Eliane; CÉZAR, Thais M. Divulgação e a adoção do método global de ensino da leitura no Rio Grande do Sul (1940-1970). In: ENCONTRO DA ASSOCIAÇÃO SUL-RIOGRANDENSE DE PESQUISADORES EM HISTÓRIA DA EDUCAÇÃO - ASPHE, IX, 2003, Porto Alegre. Anais [...] Porto Alegre: Seiva/ASPHE, 2003. p. 173-185.

PERES, Eliane; PORTO, Gilceane Caetano. A produção e a circulação de cartilhas do método global de contos de ensino da leitura no Rio Grande do Sul (décadas de 40-70). In: LEAHY-DIOS, Cyana (org.). Espaços e tempos de educação. Rio de Janeiro: Brasa/C.L. Edições, 2004. p. 26-40.

PERES, Eliane; RAMIL, Chris de Azevedo. Cartilhas produzidas por autoras gaúchas: um estudo sobre a circulação e o uso em escolas do Rio Grande do Sul (1940-1980). Revista Brasileira de Alfabetização, v. 1, p. 177-203, 2015.

PERES, Eliane; RAMIL, Chris de Azevedo. Mulheres gaúchas autoras de livros didáticos (1940-1980): das deslembranças às lembranças. In: PERES, Eliane; RAMIL, Chris de Azevedo (org.). Produção e circulação de livros didáticos no Rio Grande do Sul nos séculos XIX e XX. Curitiba: Appris, 2018. p. 159-180.

PORTO, Gilceane Caetano. Divulgação e utilização do Método Global de Contos no Instituto de Educação Assis Brasil (Pelotas, 1940-1970). 2005. 150 f. Dissertação (Mestrado em Educação) - Faculdade de Educação, Universidade Federal de Pelotas, Pelotas, 2005.

QUADROS, Claudemir de. Reforma, ciência e profissionalização da educação: o Centro de Pesquisas e Orientação Educacionais do Rio Grande do Sul. 2006. 429 f. Tese (Doutorado em Educação) - Faculdade de Educação, Universidade Federal do Rio Grande do Sul, Porto Alegre, 2006.

RAMIL, Chris de Azevedo. A coleção didática Tapete Verde: do projeto à sua produção gráfica (década de 1970 - Rio Grande do Sul). 2013. 223 f. Dissertação (Mestrado em Educação) - Programa de Pós-Graduação em Educação, Faculdade de Educação, Universidade Federal de Pelotas, Pelotas, 2013.

RAMIL, Chris de Azevedo. A iconografia e a iconologia nos livros didáticos das Edições Tabajara: um estudo das imagens na Coleção Guri (Rio Grande do Sul, década de 1960). 2018. 398 f. Tese (Doutorado em Educação) - Programa de Pós-Graduação em Educação, Faculdade de Educação, Universidade Federal de Pelotas, Pelotas, 2018.

RUSCHEL, Rosa Maria; BRAUN, Flávia E. Céu Azul - pré-livro. Porto Alegre: Edições Tabajara, 1970.

SAMAIN, Etienne. As peles da fotografia: fenômeno, memória/arquivo, desejo. Visualidades, Goiânia, v. 10, n. 1, p. 151-164, jan./jun. 2012.

VIEIRA, Cícera Marcelina; VAHL, Mônica Maciel; RAMIL, Chris de Azevedo; BORGES, Francieli Daiane Borges. A produção gaúcha de livros didáticos entre os anos de 1940 a 1980. In: ENCONTRO DA ASSOCIAÇÃO SULRIO-GRANDENSE DE PESQUISADORES EM HISTÓRIA DA EDUCAÇÃO - ASPHE, 19, 2013, Pelotas/RS. Anais [...] Pelotas, RS: UFPel, 2013. p. 1-15.

Recebido em: 16/02/2021

Aceito em: 23/09/2021 